\title{
Effect of area specific mineral mixture supplementation on milk production, biochemical and blood mineral status of Black Bengal goats
}

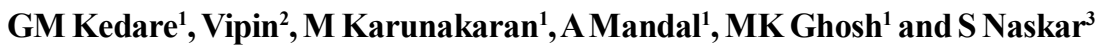

Received: 08 October 2020 / Accepted: 04 December 2020 / Published online: 07 June 2021

(C) Indian Dairy Association (India) 2021

\begin{abstract}
This study was conducted to find out the effect of area-specific mineral mixture (ASMM) supplementation on production performances, the biochemical and mineral profile of Black Bengal does during the peripartum period. For this purpose, 20 pregnant does were made into two groups according to the bodyweight viz., Control- $\mathrm{T}_{0}(\mathrm{n}=10)$ and Treatment- $\mathrm{T}_{1}(\mathrm{n}=10)$ and supplemented with 0 and $6 \mathrm{~g}$ of ASMM/animal/day, respectively starting from 3 months before the expected date of parturition to till the onset of the first post-partum estrus. Overall mean milk fat, total ash, total solids, solids not fat, milk crude protein and milk yield, blood glucose, non-esterified fatty acids, $\alpha$-amino nitrogen, phosphorus and serum glutamic pyruvic transaminase concentration were not affected by ASMM supplementation. The overall mean of serum glutamic oxaloacetic transaminase, calcium, copper, and zinc concentration in control $\left(\mathrm{T}_{0}\right)$ and treatment $\left(\mathrm{T}_{1}\right)$ groups were $127.05 \pm 1.27 \mathrm{vs} .132 .73 \pm 1.26 \mathrm{IU} / \mathrm{L}$, $7.83 \pm 0.08$ vs. $8.19 \pm 0.08 \mathrm{mg} / \mathrm{dl}, 0.66 \pm 0.02$ vs. $0.94 \pm 0.02 \mathrm{ppm}$, $0.69 \pm 0.01$ vs. $0.97 \pm 0.02 \mathrm{ppm}$, respectively and the values were higher in supplemented groups. More studies need to be conducted involving the use of ASMM supplementation to see its effect on the performance of goats.
\end{abstract}

Keywords: Area-specific mineral mixture, Biochemical, Goat, Minerals, Milk parameters

${ }^{1}$ ICAR-National Dairy Research Institute, Eastern Regional Station, Kalyani-741 235, West Bengal, India

${ }^{2}$ Center for Advanced Faculty Training in Animal Nutrition, ICARIVRI, Izatnagar, Bareilly-243 122, Uttar Pradesh, India

${ }^{3}$ ICAR-Indian Veterinary Research Institute, Eastern Regional Station, Kolkata-700037, West Bengal, India

Vipin $(\square)$

Center for Advanced Faculty Training in Animal Nutrition, ICAR-

IVRI, Izatnagar, Bareilly-243 122, Uttar Pradesh, India

Email:vipinsingh729@gmail.com

\section{Introduction}

Goats (Capra hircus) are reared by farmers for purposes like meat, milk, hides, hair and dung. Black Bengal (Capra hircus bengalensis) breed of goat is mostly reared in the eastern and north-eastern region of India. Black Bengal goat is a smaller in body size but highly prolific and meat-type breed of goat and it has many desirable productive traits like early sexual maturity i.e. 6-8 months of age. Nutritional status affects the production potential and reproductive performance of farm animals. More often goats are generally malnourished, particularly with regards to micronutrients. There are twenty-two mineral elements which are very much essential for the health and production of animals (Sharma et al. 2009). Micro-minerals supplementation is required as most of the roughages, greens, concentrates are deficient in trace mineral elements. Ghosh et al. (2013) reported six minerals namely $\mathrm{Ca}, \mathrm{P}, \mathrm{Zn}, \mathrm{Cu} \mathrm{Co}, \mathrm{Mn}$ are deficient in lower Gangetic part of West Bengal. But till now, the impacts of area specific mineral mixture (ASMM) on production performance of Black Bengal goat have not been studied. Concept of the area a specific mineral mixture is a new approach of low input and high output for the end-users. There is an abundant opportunity for exploiting the idea of ASMM for adjusting the deficiency of minerals to obtain the optimal production potential of animals to improve the economy of farmers.

\section{Materials and Methods}

\section{Experimental animals}

This study was approved by the Institutional Ethics Committee of ICAR-National Dairy Research Institute, India. Twenty numbers of Black Bengal does of $1^{\text {st }}$ parity maintained at ERSIVRI, Kalyani farm was selected and divided randomly into 2 groups of 10 animals each based on their body weight viz., control $\left(\mathrm{T}_{0}\right)$ and treatment $\left(\mathrm{T}_{1}\right)$. Control animals were managed under complete grazing with supplementation of concentrate @300 g/ head/day starting from three months before parturition until the appearance of the first post-partum estrus. The animals in the treatment group were fed the same diets as in control group except supplemented with ASMM @ $6 \mathrm{~g} / \mathrm{head} /$ day. This area 
specific mineral mixture was prepared (Table 1) as per Ghosh et al. (2013).

\section{Chemical analysis of feeds}

Proximate composition of feeds and fodders was analysed as per AOAC (2005) and cell wall constituents were estimated as per Van Soest et al. (1991). One g representative samples of feeds and fodders fed to goats were taken and tri-acid digestion (HNO3: $\mathrm{HClO}_{4}: \mathrm{H} 2 \mathrm{SO} 4$ in ratio 3: 2: 1) was done for 1 to $2 \mathrm{~h}$ until the solution was clear. The samples were filtered with Whatman 42 filter paper. Then, a sufficient amount of deionized water was added to make the final volume up to $100 \mathrm{ml}$ and samples were analysed by using AAS (Agilent-200 model). Plasma minerals were also analysed.

\section{Analysis of blood parameters}

Blood samples were collected at the weekly intervals from the jugular vein into heparinised tubes (20 IU heparin/ml of blood) and centrifuged at $3000 \mathrm{rpm}$ for $30 \mathrm{~min}$ at $4^{\circ} \mathrm{C}$ and plasma was separated and kept in the labelled storage vials of $5 \mathrm{ml}$ capacity and stored at $-20^{\circ} \mathrm{C}$ till analysis. For determination of plasma NEFA, copper soap extraction methods modified by Shipe et al. (1980) was followed. Blood $\alpha$-amino nitrogen concentration was estimated as per Goodwin (1970). Blood glucose was estimated using commercially available glucose test kit (GOD-POD Method, Span Cogent Diagnostics Ltd., India Product no\# 93DP100-74). Alanine amino transaminase (ALT) and aspartate aminotransferase (AST) were estimated by 2, 4-DNPH (Reitman and Frankel Method) using a commercial kit (Span Diagnostics Ltd., India). Blood calcium was estimated using a commercially available calcium kit (Span Diagnostics Ltd., India; product no. 87L S100-60).

\section{Estimation of milk composition}

Milk samples were collected on day3 after parturition and then fortnightly till first postpartum heat. Complete milking was done, milk was collected aseptically in the clean and sterile sampling bottles. The milking was done in the morning and evening on the days of sample collection to assess the milk production. $10 \mathrm{ml}$ of milk sample was preserved separately for total protein estimation while, the remaining portion was used for fat, solid-not fat, total solids and ash estimation.

Milk fat was estimated as per Gerber, (1892), the fat percentage was read directly by especially a calibrated butyrometer. For the estimation of milk total solids, $10 \mathrm{~g}$ of milk sample was taken in pre-weighted silica crucible placed at $80^{\circ} \mathrm{C}$ in the hot air oven for overnight. Next day sample with crucible was weighed. Total solids and SNF contents were estimated by the difference. For estimation of milk total ash dry sample with silica, crucible was ashed at $550^{\circ} \mathrm{C}$ in a muffle furnace for $3 \mathrm{~h}$ and total ash was estimated by the difference in weight after ashing of dried sample.
The total nitrogen was estimated (AOAC 2005). Total nitrogen content was multiplied by 6.38 to get milk protein value.

\section{Statistical analysis}

Different statistical designs were considered to the analysis of data as per Snedecor and Cochran (1994) and analysis was carried out through the SPSS v16.

\section{Results and Discussion}

\section{Mineral status of feeds}

The average concentration of calcium $(\mathrm{Ca})$, phosphorus $(\mathrm{P})$ copper $(\mathrm{Cu})$ and zinc $(\mathrm{Zn})$ in green fodder were $0.25 \%, 0.38 \%, 7.98$ $\mathrm{ppm}$, and $44.46 \mathrm{ppm}$, respectively with corresponding values of $0.25 \%, 0.24 \%, 7.53 \mathrm{ppm}$, and $38.75 \mathrm{ppm}$, in concentrate mixture (Table 2). The fodders were deficient in P. The lower P level could be attributed to low $\mathrm{pH}$ of the soil (Singh et al. 2011) and the ionic acidity of soil might be induced the formation of a complex with iron and thereby lowered the availability of inorganic $P$. The critical concentration of $\mathrm{Zn}$ for feeds and fodder is $30 \mathrm{ppm}$ (McDowell et al. 1983). Panda et al. (2016) reported content of $\mathrm{Mn}, \mathrm{Cu}$ and $\mathrm{Zn}$ in different feed and fodder varied between 17.14-54.29, 4.55-38.90 and 17.51-47.78 ppm, respectively in the western undulating region of Orissa. Das et al. (2003) reported the feed and fodder available for animal feeds in hill zone region West Bengal were a good source of $\mathrm{Cu}(17.97-38.73 \mathrm{ppm})$ moderate source of $\mathrm{Ca}(0.26-$ $89 \%)$ and $\mathrm{Zn}(31.91-57-35 \mathrm{ppm})$ and a poor source of $\mathrm{P}(0.14-$ $17 \%$ ). Samanta and Samanta (2002) studied in the coastal saline zone of West Bengal and noticed, the available feeds and fodder were sufficient in $\mathrm{Ca}, \mathrm{Cu}$ and $\mathrm{Zn}$ but deficient in $\mathrm{P}$ concentration Similar findings have been reported earlier from the north-eastern part of India (Chander Datt and Aruna Chhabra 2005, Hegde et al. 2016, 2018).

\section{Effect of the area-specific mineral mixture (ASMM) on milk yield and composition}

The milk yield and composition were similar in two groups indicating that ASMM supplementation has no significant effect on these variables Table 3. Singh et al. (2016), Wu et al. (2000), Sharma et al. (2002), Rabiee et al. (2010) and Begum et al. (2010) reported non-significant $(\mathrm{P}>0.05)$ effect of feeding ASMM on milk components such as protein, fat and SNF of milk on. This

Table 1 Mineral composition of area specific mineral mixture

\begin{tabular}{lc}
\hline Minerals & Quantity $(\mathrm{g})$ \\
\hline Calcium & 25.96 \\
Phosphorus & 20.08 \\
Zinc & 0.529 \\
Copper & 0.258 \\
Cobalt & 0.027 \\
Manganese & 0.011 \\
\hline
\end{tabular}


Table 2 Chemical composition (\% DM basis) and mineral status of concentrate and green fodder

\begin{tabular}{llc}
\hline Attributes & Concentrate mixture & Green fodder \\
\hline Dry matter (\%) & $93.9 \pm 0.12$ & $17.13 \pm 2.33$ \\
Organic matter (\%) & $93.72 \pm 0.07$ & $86.81 \pm 0.63$ \\
Crude protein (\%) & $18.94 \pm 0.60$ & $12.82 \pm 1.73$ \\
Ether extract (\%) & $4.51 \pm 0.10$ & $2.66 \pm 0.27$ \\
Total ash (\%) & $6.28 \pm 0.07$ & $12.92 \pm 0.62$ \\
Acid Insoluble ash (\%) & $1.77 \pm 0.06$ & $3.36 \pm 0.28$ \\
Neutral detergent fiber (\%) & $32.54 \pm 1.67$ & $57.6 \pm 5.65$ \\
Acid detergent fiber (\%) & $11.20 \pm 1.98$ & $35.91 \pm 4.08$ \\
Calcium (\%) & 0.25 & 0.25 \\
Phosphorus (\%) & 0.24 & 0.38 \\
Copper (ppm) & 7.53 & 7.98 \\
Zinc (ppm) & 38.75 & 44.46 \\
\hline
\end{tabular}

Table 3 Effect of ASMM on milk yield and milk composition

\begin{tabular}{llll}
\hline Attributes & Control $\left(\mathrm{T}_{0}\right)$ & Treatment $\left(\mathrm{T}_{1}\right)$ & $\mathrm{P}$ \\
Milk fat (\%) & $5.74 \pm 0.03$ & $5.86 \pm 0.04$ & $>0.05$ \\
Total solids (\%) & $15.16 \pm 0.19$ & $15.23 \pm 0.15$ & $>0.05$ \\
Total ash (\%) & $0.78 \pm 0.01$ & $0.80 \pm 0.01$ & $>0.05$ \\
Solid not fat (\%) & $8.64 \pm 0.02$ & $8.71 \pm 0.03$ & $>0.05$ \\
Crude protein (\%) & $3.63 \pm 0.04$ & $3.67 \pm 0.05$ & $>0.05$ \\
Milk yield (g/day) & $281.49 \pm 19.91$ & $312.43 \pm 16.20$ & $>0.05$ \\
\hline
\end{tabular}

finding also supported by Singh et al. (2016), Tiwari et al. (2013), Sahoo et al. (2017) and Nocek et al. (2006) who found the nonsignificant difference improvement in overall milk yields of control and area specific mineral mixture supplemented group. Singh et al. $(2020)$ reported after introducing $(50 \mathrm{~g})$ mineral mixture in the feed, average milk yield, fat and SNF content increased by 6.2 , 5.3 and $1.8 \%$, respectively, while milk yield increased by $0.49 \mathrm{~L} /$ day/animal.

\section{Effect of ASMM on blood parameters}

Non-esterified fatty acids (NEFA) and $\alpha$-amino nitrogen (AAN) values differed non-significantly $(\mathrm{P}<0.05$; Table 4$)$ among groups at different time intervals. NEFA is produced due to the adipose tissue breakdown of fat in response to negative energy status. These circulating NEFAs are absorbed and metabolized for energy. The concentration of NEFA directly reflects the amount of adipose tissue breakdown. Clinical experience suggests serum NEFA concentrations are more sensitive to energy balance changes compared with body condition scoring in growing situations (Van Saun, 2000). Blood $\alpha$-amino nitrogen indicates protein synthesis status of the animal, but here, the results indicate sufficient protein ration was provided in both groups. Hornick et al. $(1996,1998)$ reported plasma $\alpha$-amino nitrogen increases during growth. Mondal and Prakash (2003) reported plasma $\alpha$-amino nitrogen concentration increases, as the buffalo's age increases. Godara et al. (2015) reported no significant difference $(\mathrm{P}>0.05)$ in AAN levels between treatment and control group when supplemented with an area specific mineral mixture in black Bengal goats.

Blood glucose level was also similar in both the control and ASSM supplemented groups. Similar to our result, Ashry et al. (2012) and Behera et al. (2012) reported that feeding mineral mixture did not have any significant effect on blood glucose concentration. Contrary to our result, Godara et al. (2015) reported a significant difference $(\mathrm{P}<0.05)$ in glucose levels between treatment and control group when supplemented with area specific mineral mixture in black Bengal goats.

\section{Effect of area-specific mineral mixture on serum enzymes}

The plasma ALT level was similar in two treatment groups, however, plasma AST level was higher $(\mathrm{P}<0.05$; Table 4) group $\mathrm{T} 1$ but its concentration was within the normal value. Similar to our results, Godara et al. (2015) reported a significant difference $(\mathrm{P}<0.05)$ in AST levels between treatment and control group when supplemented with area specific mineral mixture in black Bengal goats. Sharma et al. (2011) and Exton (1980) also observed that AST and ALT level was higher in mineral supplemented group as compared with the control group. Pandey et al. (2018) and Chaudhary and Patel (2019) observed no significant change in on serum AST concentration due to supplementation of either commercial or ASMM. 


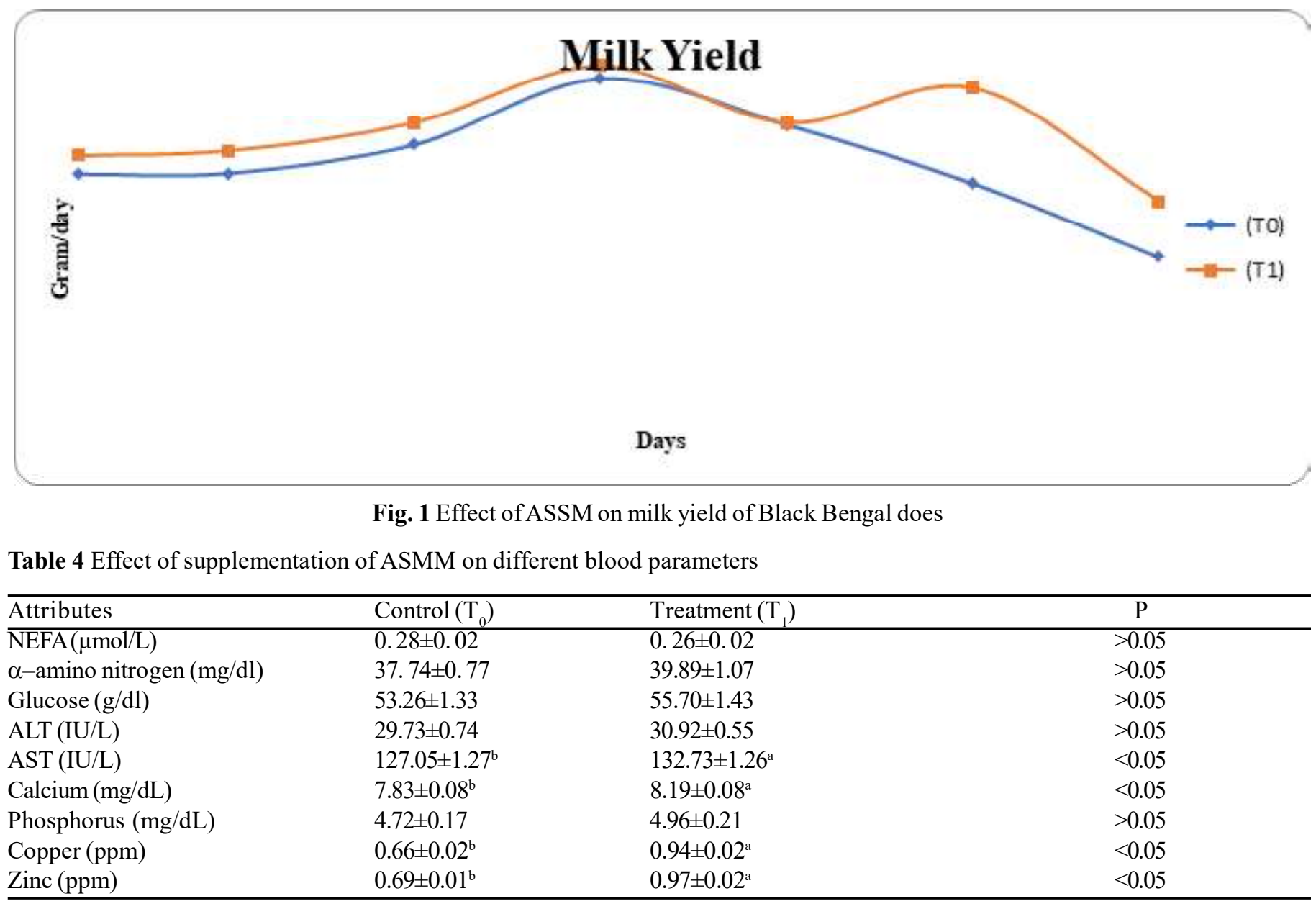

a.b values bearing different superscripts in column differ significantly $(\mathrm{P}<0.05)$ from each other

\section{Effect of area-specific mineral mixture on plasma mineral profile}

The overall mean value $\mathrm{Ca}$ was higher $(\mathrm{P}<0.05)$ in the $\mathrm{T} 1$ group (Table 4). This might be because, vitamin D in the intestinal mucosa as 1,25-dihydroxycholecalciferol acted by the opening of $\mathrm{Ca}$ channel and facilitates $\mathrm{Ca}$ uptake and transfer with the help of $\mathrm{Ca}$ binding protein (Hurwitz, 1990). Phosphorus concentration was found to be similar in both groups. The overall mean of copper $(\mathrm{Cu})$ and zinc $(\mathrm{Zn})$ differed significantly $(\mathrm{P}<0.05$; Table 4$)$ between the groups due to supplementation of ASMM which contains these minerals. Similar results were supported by other workers (Upadhyay, 2004; Chaudhary and Patel 2019; Niaz et al. 2017; Agrawalla et al. 2017 and Samanta et al. 2005).

\section{Conclusions}

It is concluded that supplementation of area-specific mineral mixture significantly improved the $\mathrm{Ca}, \mathrm{Zn}$ and $\mathrm{Cu}$ concentration in plasma of Black Bengal does. Though supplementation of ASSM did not have significant improvement in milk production and its composition, more studies need to be carried out to see the effect of supplementation of the area-specific mineral mixture on the overall performance of goats.

\section{Acknowledgements}

The authors thank ICAR-NDRI (Deemed University), India for providing suitable experimental facilities.

\section{References}

AOAC (2005) Official Methods of Analysis. 18th Edition, Association of Official Analytical Chemists, Maryland, USA

Agrawalla J, Sethy K, Behera K, Swain RK, Mishra SK, Sahoo N, Mohapatra MR, Khadenga S (2017) Improved reproductive performance of crossbred cattle in Puri district of Odisha following supplementation of area specific mineral mixture. Indian J Anim Reprod 38: 43-45. 19

Begum I, Azim A, Akhter S, Anjum MI, Afzal M (2010) Mineral dynamics of blood and milk in dairy buffaloes fed on calcium and phosphorus supplementation. Pakistan Vet J 30: 105-109

Behera PC, Das M, Tripathy DP, Panigrahi B, Panda N (2012) Mineral supplementation and its relevance in improving conception rate in anestrus and repeat breeding heifers. Intas Polivet 13: 17-21 
Chander Datt and Aruna Chhabra (2005) Mineral status of Indian feeds and fodders: A review. Indian J. Dairy Sci 58: 305-320

Chaudhary RK, Patel DC (2019) Augmenting blood profile and reproduction in buffaloes of tribal areas of Vadodara district (Gujarat) through appropriate mineral mixture supplementation. The Indian J Vet Sci Biotechnol 14: 51-55

Das A, Biswas P, Rajendran D (2003) Micronutrient profile of feeds, fodders and animals in hill zone of West Bengal. Anim Nutr Feed Technol 3: 9-16

Devasena B, Reddy IJ, Ramana JV, Prasad PE, Prasad JR (2010) Effect of Supplementation of Area specific mineral mixture on reproductive performance of crossbred cattle a field study. Indian J Anim Nutr 27: 265-270

El Ashry GM, Hassan AAM, Soliman SM (2012) Effect of feeding a combination of zinc, manganese and copper methionine chelates of early lactation high producing dairy cow. Food Nutr Sci 3:

Exton JH (1980). Effect of diets low in calcium and phosphorus on development of growing lambs. Ameri J Physio 3: 235-238

Gerber N (1892) Die acid-butyrometrie, eine neue fettbestimmungs modification. Milch-Zeitung 53: 390-892

Ghosh MK (2013) Area-specific mineral formulation for feeding of yak and yak cattle hybrid. ERS, NDRI, Kalyani, West Bengal, India

Godara RS, Naskar S, Das BC, Godara AS, Ghosh MK, Mondal M, Bhat SA (2015) Effect of area specific mineral supplementation on biochemical profile in female Black Bengal goats. J Anim Res 5: 263-268

Goodwin JF (1970) Spectrophotometric quantitation of plasma and urinary amino nitrogen with flurodinitrobenzene. Stand Meth Clin Chem 6: 89-98

Hegde M, Jaisunder S, Kumaresan A, Datt C, Singh P, Singh A (2016). Micro mineral concentration in soil, plant and dairy cattle in Andaman Group of Islands. Indian J Anim Nutr 33: 394-398

Hegde M, Jaisunder S, Singh P, Datt C (2018) Macro mineral status in soil, plant and dairy cattle in Andaman group of islands. Indian J Anim Nutr 35: 415-420

Hornick JL, Eenaeme CV, Gauthier S, Baldwin P, Istasse L (1996) Glucose, alpha-amino nitrogen, and amino acid exchange across the hind limb in young double-muscled type bulls maintained at two growth rates. Canadian J Anim Sci 76: 193-202

Hornick JL, Van Eenaeme C, Diez M, Minet V, Istasse L (1998) Different periods of feed restriction before compensatory growth in Belgian Blue bulls: II. Plasma metabolites and hormones. J Anim Sci 76:260271

Husain SS (1999) Sustainable genetic improvement of economic traits of Black Bengal goats through selective and crossbreeding. Bangladesh Agricu University Res Progr 10:72-80

McDowell LR, Conrad JH, Ellis GL, Loosli JK (1983) Minerals for grazing ruminants in tropical regions (p. 112). Gainesville: University of Florida.

Mondal M, Prakash BS (2003) Changes in plasma GH, LH and progesterone and blood metabolites following long-term exogenous somatoliberin administration ingrowing buffaloes (Bubalus bubalis). J Anim Vet Adv 2: 259-270

Niaz F, Sethy K, Swain RK, Behera K, Mishra SK, Karna DK, Mishra C (2017) Combined effect of concentrate and area specific mineral mixture supplementation on the performance of Ganjam goat in its native tract. Pharma Innovation 6: 320-323

Nocek JE, Socha MT, Tomlinson DJ (2006) The effect of trace mineral fortification level and source on performance of dairy cattle. J Dairy Sci 89:2679-2693.

Panda M, Panda N, Panigrahi B, Swain RK, Mishra A (2016) Mineral profile and metabolic status of cattle in western undulating zone of Odisha. Indian J Anim Nutr 33: 290-295
Pandey VK (2018) Effect of Area specific mineral mixture on serum biochemical parameters and milk yield in dairy cattle. Intl J Agric Sci 10: 4965-4968

Rabiee AR, Lean IJ, Stevenson MA, Socha MT (2010) Effects of feeding organic trace minerals on milk production and reproductive performance in lactating dairy cows: a meta-analysis. J Dairy Sci 93: 4239-4251

Sahoo B, Kumar R, Garg AK, Mohanta RK, Agarwal A, Sharma AK (2017) Effect of supplementing area specific mineral mixture on productive performance of crossbred cows. Indian J Anim Nutr 34: 414-419.

Samanta CS, Mondal MK, Biswas P (2005) Effect of feeding mineral supplement on the reproductive performance of anestrous cows, Indian J Anim Nutr 22: 177-184

Samanta A, Samanta G (2002) Mineral profile of different feed and fodders and their effect on plasma profile in ruminants of West Bengal. Indian J Anim Nutr 19: 278-281

Sharma MC, Joshi C, Das G (2009) Soil, fodder and serum mineral (cattle) and haematobiochemical profile in some districts of Central Uttar Pradesh. Indian J Anim Sci 79: 411-415

Sharma J, Kumar A, Tiwari DP, Mondal BC (2011) Effect of dietary supplementation of calcium, copper and manganese on nutrient utilization, growth, blood biochemical and mineral profile in crossbred heifers, Indian J Anim Sci 81:493-497

Sharma MC, Joshi C, Sarkar TK (2002) Therapeutic efficacy of minerals supplement in macro-minerals deficient buffaloes and its effect on haematobiochemical profile and production. Asian Australasian J Anim Sci 15: 1278-1287

Shipe WF, Senyk GF, Fountain KB (1980) Modified copper soap solvent extraction method for measuring free fatty acids in milk. J Dairy Sci 63:193-198

Singh DK, Sahu SP, Teufel N (2020) Mineral mixture feeding enhances dairy animals productivity: A study of Bihar, India. Indian J Anim Nutr 37: 26-30

Singh RK, Mishra SK, Swain RK, Dehuri PK, Sahoo GR (2011) Mineral profile of feeds, fodders and animals in mid-central table land zone of Orissa. Anim Nutr Feed Technol 11: 177-184

Singh S, Chhabra S, Randhawa SNS, Randhawa CS, Gupta DK (2016) Effect of area specific mineral mixture feeding on milk yield and composition of dairy animals of central zone of Punjab. Intl J Livest Res 6: 62-65

Snedecor GW, Cochran WG (1994) Statistical methods 8th edn. Oxford and IBH Publishing Corporation, Calcutta

Sultana S, Khan M, Hassan M, Khondoker M(2012) Effects of concentrate supplementation on growth, reproduction and milk yield of Black Bengal goats (Capra hircus). Bangladesh Vet 29: 7-16

SPSS (2010). Statistical packages for Social Sciences, Version 16, SPSS Inc., Illinois, USA

Tiwari MR, Shrestha BK, Mandal P, Panday LN (2013) Growth performance of Khari goats on supplementation of urea molasses mineral block (UMMB) in fodder based diets. Nepal J Sci Technol 13: 29-32

Tiwari R, Sharma MC, Singh BP (2013) Awareness and impact of area specific mineral mixture technology in field situation. Indian J Anim Sci 83: 435-437

Upadhyay AK (2004). Effect of mineral supplementation on conception of dairy animals. Indian J Vet Med 24: 34-38

Van Saun RJ (2000) Blood profiles as indicators of nutritional status. Department of Large Animal Clinical Sciences, College of Veterinary Medicine, Oregon State University, Corvallis, Oregon

Van Soest PV, Robertson JB, Lewis BA (1991) Methods for dietary fiber, neutral detergent fiber, and nonstarch polysaccharides in relation to animal nutrition. J Dairy Sci 74:3583-3597

Wu Z, Satter LD, Sojo R (2000) Milk production, reproductive performance, and fecal excretion of phosphorus by dairy cows fed three amounts of phosphorus. J Dairy Sci 83:1028-1041 